\title{
Preface to the Third Issue of Indian-Pacific Journal of Accounting and Finance
}

I have the honour and privilege to welcome you to the Vol. 1 Issue 3 of Indian-Pacific Journal of Accounting and Finance. In this Issue 3, the journal emphasises on accounting information system, corporate governance and risk management, accounting regulation and financial reporting, and accounting.

In the first paper with the caption "Examining AIS Software and Co-operatives Performance in Malaysia", Mr Mohd Hadzrami Harun Rasit (Tunku Puteri Intan Safinaz School of Accountancy, Universiti Utara Malaysia) and Dr Mohammad Azhar Ibrahim (Tunku Puteri Intan Safinaz School of Accountancy, Universiti Utara Malaysia) examine the use of Accounting Information System (AIS) software in the context of Malaysian cooperatives. The objectives of this paper are categorised into two, namely: to document the types of AIS software used by co-operatives, and to examine the relationship between the types of AIS software used and performance of the co-operatives. Furthermore, the paper draws on the resource-based view (RBV) to examine the gap issue. Findings from this study suggest that commercial and developed-in-house AIS software are mostly used by co-operatives. Also, the results reveal that co-operatives performance is not associated with the types of AIS software used by the co-operatives. The research provides valuable insights into the implementation of AIS among Malaysian co-operatives, which has received little attention thus far from academic, governmental and professional bodies.

In the second paper with the title "A Review of Financial Distress Prediction Models: Logistic Regression and Multivariate Discriminant Analysis", Mr Ehsan ul Hassan (School of Economics, Finance and Banking, Universiti Utara Malaysia), Dr Zaemah Zainuddin (School of Economics, Finance and Banking, Universiti Utara Malaysia), Dr Sabariah Nordin (School of Economics, Finance and Banking, Universiti Utara Malaysia) present a review of literature for early prediction of financial bankruptcy. The study contributes to the formation of a systematic review of the literature regarding previous studies done in the field of bankruptcy. It addresses two most commonly used financial distress prediction models, that is, multivariate discriminant analysis and logit regression. Models are discussed with their advantages and disadvantages. After methodological review, the authors advance that logit regression model (LRM) might perhaps have more advantages than multivariate discriminant analysis (MDA) for better prediction of financial bankruptcy. However, accurate prediction of bankruptcy is beneficial to improve the regulation of companies, to form policies for companies and to take any precautionary measures if any crisis is about to come in future.

In the third paper captioned "Accounting Regulation and Financial Reporting Quality: Pre-and-Post IFRS Nigeria Evidence”, Philip Jehu (Federal University Kashere, Gombe, Nigeria) and Dr Mohammad Azhar Ibrahim (Tunku Puteri Intan Safinaz School of Accountancy, Universiti Utara Malaysia) examine whether accounting regulation is associated with financial reporting quality in Nigeria. The authors use accrual-based earnings management construct - abnormal accruals as a proxy for financial reporting 
quality. The study reveals some significant variation in abnormal accruals with the implementation of International financial reporting standards (IFRS) to regulate accounting practice. Similarly, the research finds that the control variables - firm size, leverage, and return on asset have significant effects on financial reporting quality. This study aligns and consistent with previous studies indicating the effectiveness of IFRS adoption in improving financial reporting quality. The study contributes to the discussion on IFRS adoption across reporting environments. Regulatory agencies in Nigeria might need to consider the combined effect of other corporate governance laws to ensure quality reporting. The study is limited by our sample (2009 - 2014), and by the proxies for both accounting regulation and financial reporting quality, the data of which was in most part handpicked. The authors recommend future research to consider perhaps testing the combined effect of other corporate governance variables like audit committees and board characteristics.

In the fourth paper entitled "Investigating Ownership Structure, Company Characteristics and Online Environmental Disclosure in Malaysia", Dr. Ali Saleh Ahmed Al_arussi (Xiamen University Malaysia) and Dr. Redhwan Ahmed Al_dhamari (Tunku Puteri Intan Safinaz School of Accountancy, Universiti Utara Malaysia) focus on environmental disclosure on the Internet and examine whether ownership structure and company characteristics have a significant association with the level of Internet environmental disclosure (IED) amongst Malaysian companies. Six variables management ownership, government ownership, firm size, level of technology, industry type, and profitability - have been chosen to be examined in this study. Multiple regression analysis is used to test these relationships by analysing the data of 201 online annual reports on the websites of Malaysian companies. The results indicate that government ownership, firm size, level of technology and industry type are positively and significantly associated with IED; management ownership is negatively and significantly associated with IED, and profitability did not show a significant relationship. The results of this paper can be used by regulators to enhance and regulate online environmental reports as it is still voluntary based.

In the fifth paper with the title "Examining the Livelihood Assets and Sustainable Livelihoods among the Vulnerability Groups in Malaysia", Dr Ahmad Zubir Ibrahim (School of Government, Universiti Utara Malaysia), Dr Kalthum Hassan (School of Government, Universiti Utara Malaysia), Dr Roslina Kamaruddin (School of Economics, Finance and Banking, Universiti Utara Malaysia), and Associate Prof. Dr. Abdul Rahim Anuar (School of International Studies, Universiti Utara Malaysia) investigate the relationship between livelihood assets and sustainable livelihoods. The study is in response to the livelihood vulnerability group such as paddy farmers, coastal fishers and rubber tappers in rural areas, which are susceptible to economic shock and climate change such as flood and drought. This condition will, no doubt, jeopardise the livelihoods of this group and hence the research gap. This study adopts quantitative study with stratified sampling method to select a total of 600 respondents from rural areas in Kedah and Kelantan. The findings confirm that physical asset, natural asset and social asset are significantly related to the achievement of sustainable livelihoods. Some recommendations have been highlighted to assist the concerned parties in improving sustainable livelihoods among the vulnerable group in rural areas.

As you read through this Vol. 1 Issue 3 of IPJAF, I would like to summarise that the success of the journal depends on your active participation and those of your colleagues and friends through submission of high-quality articles within the journal scope for review and publication. 
I beseech our revered authors to enjoy the benefits IPJAF provides about mentoring nature of the unique review process that offers high quality and helpful reviews tailored to improving their manuscripts.

I acknowledge your support as we endeavour to make IPJAF the most authoritative journal on accounting and finance for the community of academic, professional, industry, society and government.

\section{Oluwatoyin Muse Johnson Popoola, PhD}

Editor-in-Chief

popoola@omjpalpha.com 